
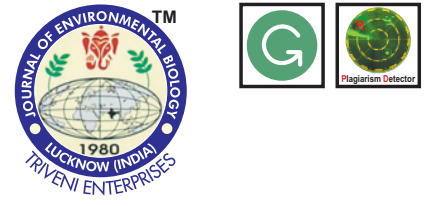

DOI : http://doi.org/10.22438/jeb/38/5(SI)/GM-32

\title{
Geomorphic attributes involved in sustainable ecosystem management scenarios for the Ignis-Gutai Mountains Romania
}

\author{
Authors Info \\ M. Ilies' ${ }^{1}$, G. Ilies ${ }^{1 *}$, M. Hotea ${ }^{1}$ \\ and J.A. Wendt ${ }^{2}$ \\ ${ }^{1}$ Extension of Sighetu Marmatiei, \\ Faculty of Geography, "Babes- \\ Bolyai" University, Sighetu \\ Marmatiei, 435 500, Romania \\ ${ }^{2}$ Department of Regional \\ Development Geography, \\ University of Gdansk, Gdansk, \\ 80-309, Poland
}

*Corresponding Author Email : gabriela.ilies@ubbcluj.ro

Key words

Exploratory scenario, Geomorphic attributes, Integrative scenario, Ignis-Gutai Mountains

Publication Info

Paper received : 18.10.2016

Revised received : 25.06.2017

Accepted : 27.06.2017

\section{Abstract}

Aim : The paper presents the geomorphic attributes involved in a scenario for sustainable ecosystem management in several protected areas of Ignis-Gutai Mountains Romania.

Methodology : Geoforms are frequently used to substantiate decisions or to communicate impact assessment tools, due to their supporting role and to the readable features on maps. The present study used a multi-scale and layered approach, forged for the goals of the local stakeholders (including discussions with them and with the scientific community).

Results : Different types of scenarios, integrative and explorative versions, for the Local Action Group Mara-Guta i (a n intercommunal privatepublic association that acts as a main funding body for small development projects in the area) served to determine the relevance of geomorphic attributes involved in the sustainable ecosystem management scenario.

Interpretation: Morphographic, morphometric and morphogenet ic approaches highlight the i m portance of communicating these scenarios via a set of maps and graphs focusing on geoforms.

\section{Sustainable Ecosystem Management (SEM)}

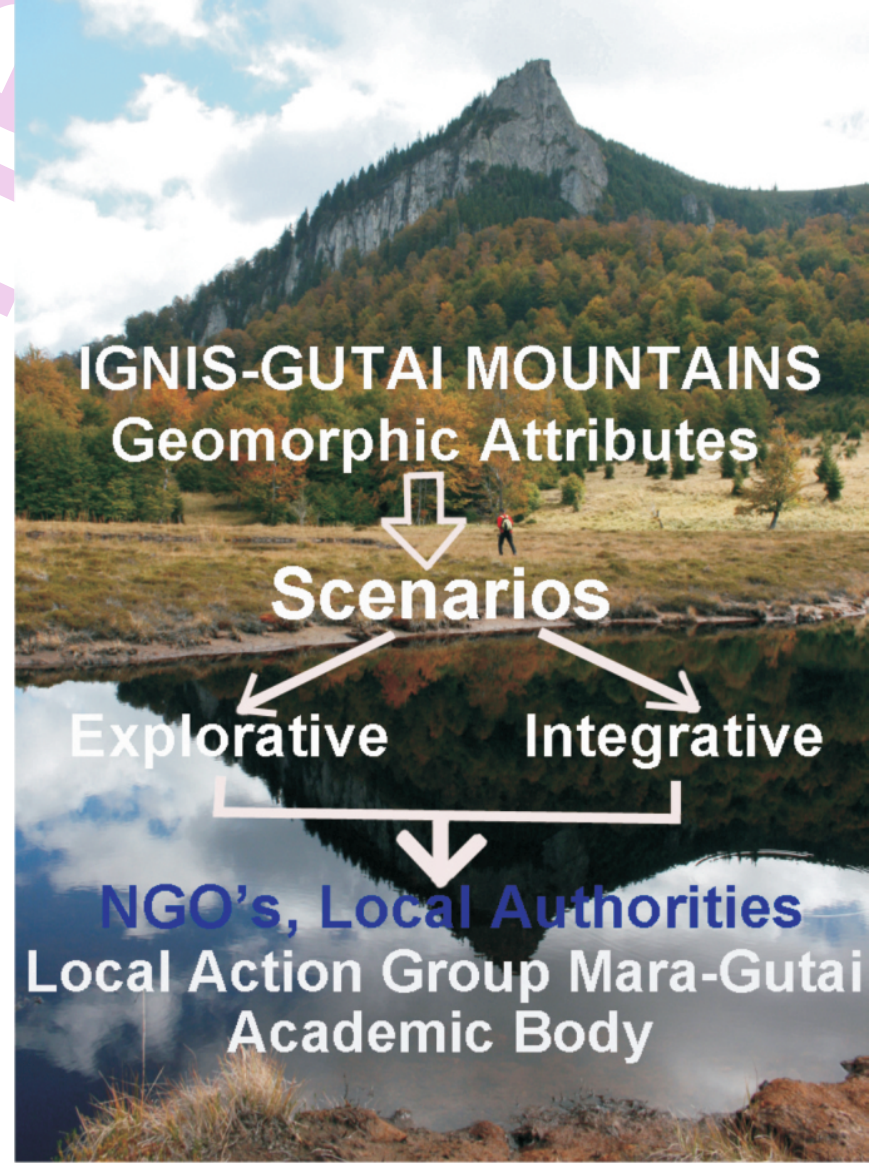




\section{Introduction}

Sustainable ecosystem management scenarios are used to substantiate management plans for protected areas. In Romania, the implementation process of management plans for several protected areas is delayed and the custodians find themselves in difficult position. The stakeholders in the reserves have development goals as human well-being, competitiveness, sustainability of their activity etc., without a comprehensive sustainable ecosystem management scenario or set of guidelines. Therefore, NGO's, local action groups, universities act as place-holders, developing appropriate scenarios to facilitate the continuity of several activities within the protected areas. This is the case of Local Action Group Mara-Gutai (LAG$M G)$, a LEADER private-public intercommunal associative form and funding body for small development projects in its territory. LEADER is the acronym in French for "Links between actions for the development of the rural economy", a European Union initiative that supports rural development projects initiated at the local level (URL-1).

Scenarios are built to enhance the understanding of the future processes, as "coherent and internally consistent set of assumptions about key-driving forces and relationships" (Priess and Hauck, 2016), but not for predictions. Environmental scientists applied sectorial analysis for several protected areas in Romania and substantiated two types of scenario: Business as usual and sustainable ecosystem management in order to present ecosystem services (UNDP/GEF, 2012). These scenarios have been adapted to the present study, focusing on the support function of the geoforms.

In order to promote sustainable activities in the limits of the reserves and protected areas, a research study was carriedout by Babes-Bolyai University researchers, during 2014-2015, commissioned by LAG Mara-Gutai. The main objective of the research project was to scientifically substantiate a sustainable management plan for the LAG members, using a scenario-based method, considered more accessible to the local economic and social stakeholders (llies et al., 2014).

Geomorphic attributes were part of the complex scenario due to the local specificity. These attributes were used to build an explorative and integrative sustainable ecosystem management scenario starting from the hypothesis that the local community's environmental awareness is traditionally based on the sustainable valorisation of the land, in accordance with the landform, landscape and productivity (Pletsch et al., 2014). Accessibility issues were also tackled. Therefore, the paper looks at the management scenarios from the perspective of geomorphic attributes, as physical support, essential for the understanding of processes developed within the protected areas at this scale. A triple faceted approach was used to determine the relevance of them in the sustainable ecosystem management scenario: morphographic, morphometric and morphogenetic.

\section{Materials and Methods}

Ignis and Gutai mountains are situated at the western and southern limit of Maramures Land. They are the oldest sector of the volcanic range in Eastern Carpathians. Separated by mountain passes from the neighbouring units (Huta, 587m, Gutai, $984 \mathrm{~m}$, Neteda, 1039m) they are two separate units distinguished by geoforms originating from different types of volcanic activity: Ignis mountains as andesitic plateau, mostly stratified, with small depressions, an end cliff and residual forms, named rocks (Piatra Sapantei, Piatra Goala, Piatra Rea etc); Gutai mountains with pyroxene andesite, mostly vertical columns with a controversial neck - Creasta Cocosului and cone shaped summits. On the northern limit of the mountains, a piedmont range forms contact with the Maramures lowland, often associated with the mountain range due to the position of the settlements around the massifs.

The natural-human system forms a consistent part of a regional structure Maramures land, with a well-developed protected area domain, from the Natura 2000 sites to local reserves. The communes are organised in a local action group, Mara-Gutai (Fig.1).

The study covers several types of reserves (Table 1); protected areas of national interest (integrated in III $^{\text {rd }}$ and IV ${ }^{\text {thin }}$ in IUCN system), Natura 2000 sites (SCl and SPA) and locally designated areas (IV ${ }^{\text {th }}$ UUCN), a total of 28510.41 ha.

\section{Assessment of geomorphic attributes}

Geomorphic attributes are interesting tools for the scenario building processes due to the link to the territorial/geographical features of the human-nature couple systems in protected areas of Ignis-Gutai Mountains. Geoform classification (landforms, relief forms in general, regardless of origin, dimension or generalisation level) is the concept that provides an easier understanding of the territory for the stakeholders. It originates from the geomorphology studies carried out in the Eastern European countries, in the sixties (Zinck, 2016), reloaded by non-geographers and UN organisations in studies regarding the human well-being and resources, as FAO (2006) and Zinck (2016). GIS and thematic cartography enhances the accurate classification of geoforms to be used in the SEM scenario. The terminology used in research studies focusing on small-scale classification tables (Table 2) has a large degree of vernacular origin. It revolves mostly around general morphometric attributes (area, altitude, slope, fragmentation); land forms (types, evolution, impact factors); accessibility (roads and tourist trails); channels (river systems); and points of interest (summits, spectacular rocks, geosites). Therefore, the research used a multi-scale and layered approach, forged for the goals of the local stakeholders. The subsequent 
Table 1: Protected area within the Ignis-Gutai Mountains

\begin{tabular}{|c|c|c|c|c|c|}
\hline \multicolumn{2}{|c|}{ Type of protected area } & Number & Area (ha) & Specificty & $\begin{array}{l}\text { Relevance for SEM } \\
\text { geoform attributes }\end{array}$ \\
\hline \multicolumn{2}{|c|}{ Nationally designated areas } & 7 & 99 & $\begin{array}{l}\text { Natural monuments, } \\
\text { geological and botanical } \\
\text { IUCN III }\end{array}$ & Points of interest \\
\hline \multirow[t]{2}{*}{ Natura 2000 sites } & Natura 2000 (SCl) & 2 & 20295 & $\begin{array}{l}\text { Alpine } 95.59 \% \\
\text { Continental } 4.41 \%\end{array}$ & $\begin{array}{l}\text { Geostructures and } \\
\text { landscapes }\end{array}$ \\
\hline & Natura 2000 - (SPA) & 1 & 28406 & $\begin{array}{l}\text { Alpine } 90.56 \% \\
\text { Continental } 9.44 \%\end{array}$ & - \\
\hline \multicolumn{2}{|c|}{ Locally designated areas } & 4 & 5.41 & Habitat IUCN IV & $\begin{array}{l}\text { Channels and } \\
\text { accessibility }\end{array}$ \\
\hline
\end{tabular}

Table 2 : Geoform attributes to be integrated in SEM for the protected areas in Ignis-Gutai Mountains

\begin{tabular}{lll}
\hline Geoform & Attributes & Role in SEM \\
\hline Geostructure & Ranges & Volcanic mountain range \\
& & Piedmontan range \\
Morphogenetic & Volcanic & Residual relief \\
& & Fossil relief \\
& Epigeal & Piedmontan erosion/accumulation \\
Landscape & Profile & Altitude dependent mountain landscape \\
Relief & Plateau & Izvoare, Sapanta \\
& Escarpment & Abruptand residual volcanic forms: Piatra Sapantei, Piatra Goala, Piatra Rea \\
& Cascades: Custurii, Strungi, Sipot, Ciuroiului etc. \\
& Channels and talvegs & River valleys \\
& Gorges \\
Lithology & Petrographic & Andesite based variations \\
& Structural & Sedimentary monoclinal structures \\
Landform & Shape & Summit/peak \\
& Plateau \\
& Isolated rock \\
& Valley \\
& Hillside \\
\hline
\end{tabular}

geo-database with geoforms is essential to the development of the research on the conservation state and evolution, using specific fieldwork tools (spatial data retrieval, photographs, interviews with the main stakeholders and with locals) and GIS (open source Quantum GIS, software for mapping and visualisation). Basic classification and hierarchical clustering operations were applied to the retrieved data, in order to assess the role of each geoform range in sustainable ecosystem management(Fig.1).

Scenario building : The socio-ecological system, as defined by Smith et al. (2016) is important for the sustainable ecosystem management in the study area due to the traditional way of life and the need to coordinate different types of development projects and stakeholders (llies et al., 2010). Ecosystem management is the application of ecological science to resource management to promote long-term sustainability of ecosystems and delivery of essential ecosystem goods and services to society (Chapin et al., 2002). Management goals can be approached on categories depending on the impact indicators (high-integrity, impacted and cultural ecosystems). Geoforms are relevant on small-scale classification.

At the scale of Ignis-Gutai Mountains an integrative and explorative scenario were drawn, tackling issues regarding the context, the conceptual framework, inputs and visualisation. The integrative scenario was adapted from Priess and Hauck (2014). The goal was to provide an accurate and synthetized image on the impact assessment tools to stakeholders in the region (local authorities in LAG Mara-Gutai), with several paths, describing here only the extreme and moderate ones. This particular scenario tries to integrate a storyline in specific impact 
Table 3 : Implementation of the integrative scenario

\begin{tabular}{ll}
\hline Stages & Highlights \\
\hline Stage 1 & Establishing stakeholders' goals regarding ecotourism, agriculture, forestry activities \\
& - Workshop with local authorities, NGO's \\
& - Defining the highlights depending on priorities (also described in different strategic planning documents) \\
& - Defining interest zones within the area \\
Stage 2 & - Prowledge integration ( scientifically substantiated concepts and the highlights) \\
& - Relevant literature review, case studies and good-practice examples \\
& Quality control \\
Stage 3 &
\end{tabular}

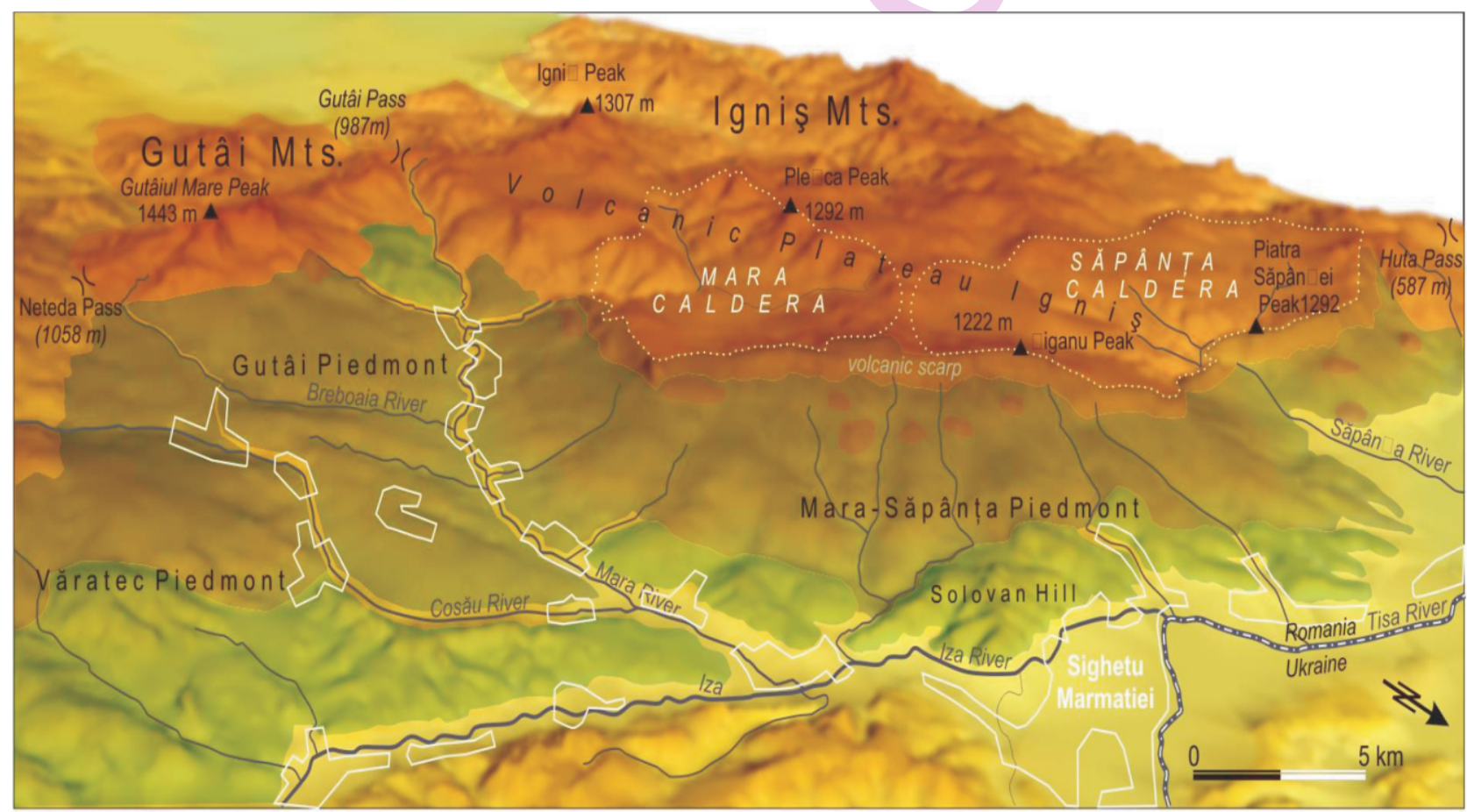

\section{Legend}

1. Geostructures

2. Points of interest

3. Administrative units

1.a.

1.b.

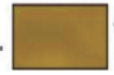

1.c.
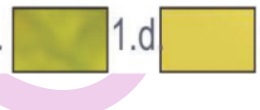

1.e.
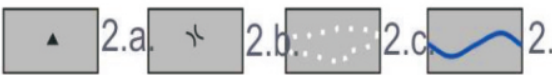

2.d. $\bigcirc$ 3.a.

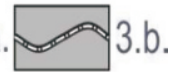

Legend: (1) Geostructures; (1a) Volcanic range with plateau relief; (1b) Volcanic scarp;(1c) Piedmontan range with hillsides and fosil relief; 1d.) Piedmontan range with accumulations; (1e) Valley; (2) Points of interest; (2a) Summits/peaks; (2b) mountain passes; (2c) calderas; (2d) rivers; (3) Administrative units; (3a) Settlements; (3b) State border.

Fig. 1 : Geoforms involved in scenario development for Ignis-Gutai Mountains 


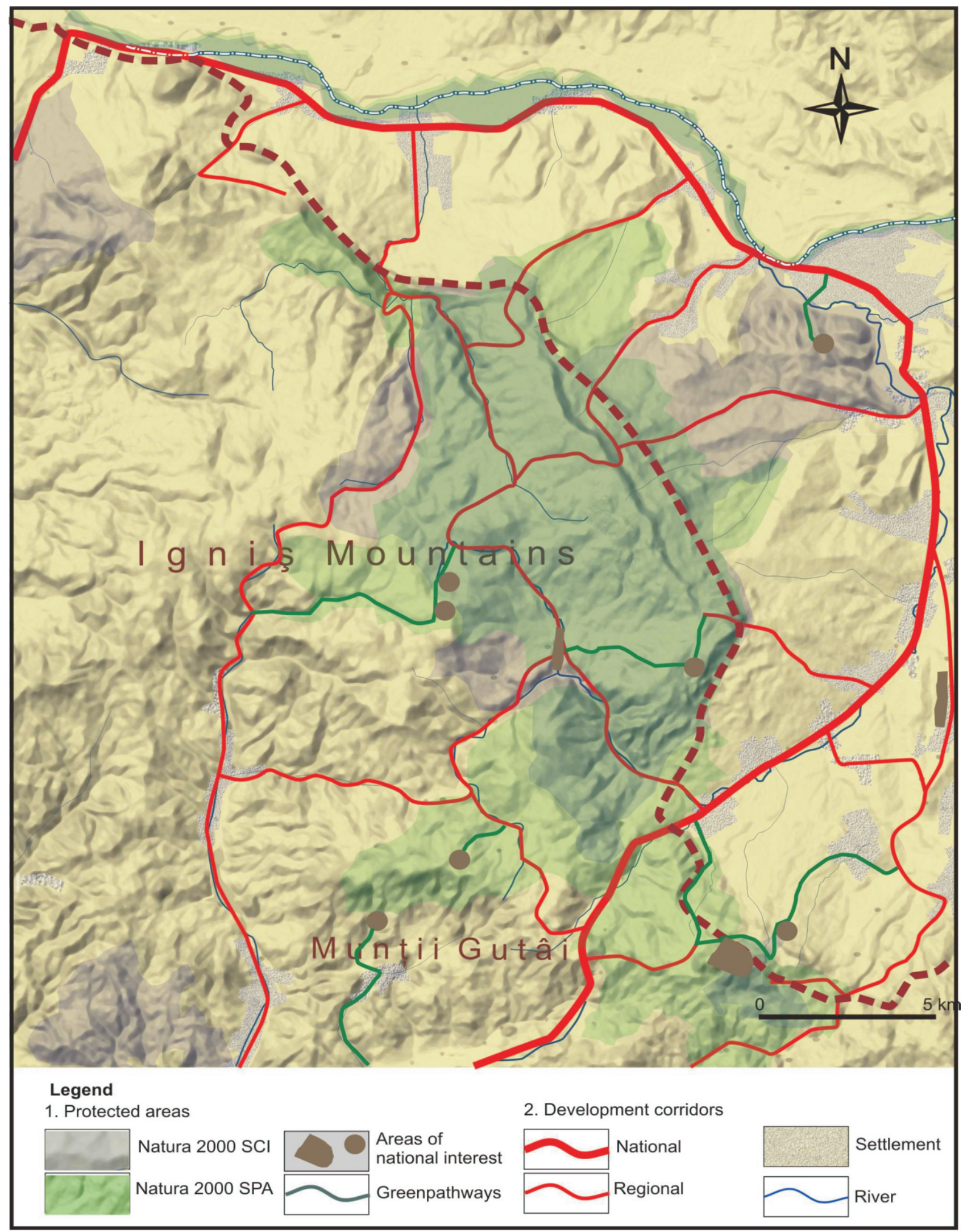

Fig. 2 : Exploratory scenario for ecotourism activities based on accessibility assessment 
assessment tools for the protected areas. This is an interdisciplinary approach, and the physical support role of the geoforms is explained by the means of a 3D representation. Preliminary work was done in GIS and graphic environments, using 3D rendering, layers with land units, morphographic attributes, land cover, infrastructure networks substantiated within studies in the field (Abousaeidi et al., 2016). The stakeholders expressed their goals linked to the subject on the thematic maps (Table 3). Furthermore, the highlights were discussed with a scholar panel at the university and NGO's representatives specialised on ecological management, protected area custodians etc. Extreme scenario was using the market first concept; the moderate scenario combined the market first with sustainability first highlights. The consistency of the scenario was checked with a group of specialists and stakeholders, and then presented to the LAG members within a meeting and publication.

The explorative scenario was more descriptive, but involving at least one significant shift in paradigm, processes' evolution without an explicit intervention on the management plans and concerns mostly the socio-ecological system (private members of the LAG Mara-Gutai). It is essentially a descriptive trend scenario used to raise awareness on the value of the ecosystem services generated by the natural tourist features of the Ignis-Gutai Mountain area, including its cultural system. The baseline was the year 2010, considering at least one major change at socio-economic level and one major natural hazard. The first stage was to characterise the socio-economic and technological driving forces: tourism infrastructure, settlement patterns, communication patterns linked to the relief, starting from statistical and geo-database derived data. Second, the relief dependent land-use and land cover mostly serves to assess vulnerability depending on several factors. Third, the tourist motivations for ecotourism were in focus, in order to evaluate the tendency for greener infrastructure usage (hiking, adventure sports, winter sports, wildlife etc) on a model by Navrátil et al. (2016). For Ignis-Gutai Mountains several studies were carried out in 2010-2015 period provided qualitative data within doctoral research grants (Pui, 2012 and 2013) and reports (WWF, 2010, UNDP/GEF, 2012).

\section{Results and Discussion}

Integrative scenario was used to explain the concepts and evolution pathways as part of a larger research "The carrying capacity of the protected areas on LAG Mara-Gutai territory, with accent on ecosystemic services" (Ilies et al., 2014). The storyline was linked to the ecotourism development, and argued that accessibility issues are driving forces for this kind of scenario. Accessibility feature analysis combined with the attractively of the points of interest (Fig.2) was the baseline for raw zonification of the protected areas. The target of completion was to be year 2035.
From the discussion with the stakeholders, at the first stage, resilience of the communities could be reached by overcoming the uncertainties linked to the tourism market. There is a strong opinion that policy is irrelevant to their goals, due to the implementation/enforcement difficulties. Sustainability goals could be met only by limiting forestry activities followed by a consistent set of compensations. There are no security issues, even considering the northern neighbour, Ukraine, as possible partner.

Accessibility issues are tackled by envisioning new roads, following the channels and talvegs, new tourist paths with a minimum infrastructure, towards the points of interest; interpretation centres (mixed nature/heritage) and signposting, entry taxes.

Extreme scenario focuses on explaining impact indicators in the high-integrity zone, on impacted and cultural ecosystems, also raising awareness on the fundamental features of the territory. Uncertainties range from the unknown deadline for the management plans' approval, to the weak coordination of projects, continuing with the understanding of natural risks and anthropogenic intervention (eg. microhydroplants, illegal deforestation). Increasing accessibility and the quality of relief based tourist infrastructure will encourage ecotourism to the limit of its carrying capacity, with a steady growth in the following 10-15 years. Decline will be triggered by the lifecycle of the tourist spots and the environmental problems issued by tourist pressure on resources, if approached by a BAU scenario. SEM scenario tackles the uncertainty with a set of activities to enhance higher quality ecotourism available to a market niche that will allow growths without putting pressure on the region's resources. Ecological stability models as argued in Michaeli et al. (2015) supplied the conceptual framework for this scenario. The map stresses-out the corridors and the geoforms as points of interest in both cases (Table 3 ).

Explorative scenario was presented to the LAG members, to the private sector in order to produce a clear image on the two types of development projects, integrated in BAU scenario and in the SEM scenario. Besides the map, a set of graphs were plotted to compare the value of ecosystem services (llies et al., 2014). Scenario BAU is based on the valorisation of the present infrastructure trend, access to the main geoforms of tourist interest and specific economic activities (agriculture, forestry). On one map there were drawn the prospective upgrades of infrastructure and were calculated the figures for the tourism businesses and the value of services for the local communities. On the second map, the visitor centres, green infrastructures, sustainable communication channels were outlined.

In conclusion, different types of scenarios, integrative and explorative versions, conceived for the Local Action Group Mara- 
Gutai, served to determine the relevance of geomorphic attributes involved in the sustainable ecosystem management scenario. Moreover, morphographic, morphometric and morphogenetic approaches highlight the importance of communicating these scenarios via a set of maps and graphs focusing on geoforms.

\section{Acknowledgment}

We greatly appreciate the input of the local stakeholders involved in the LAG Mara-Gutai and in the development process of this research.

\section{References}

Abousaeidi, M., R. Fauzi and M. Rusnah: Determining efficient delivery routes in specific time-frames using geographic information system. J. Environ. Biol., 37, Special Issue, 1167-1176 (2016).

Chapin III, F.S., A.M. Pamela and A.M. Harold: Principles of terrestrial ecosystem ecology. Springer-Verlag, New York, (2002) at http:// www.crc.uqam.ca/Publication/Principles $\% 20$ of $\% 20$ terrestrial\% 20ecosystem\%20ecology.pdf, retrieved in September 2016.

Food and Agricultural Organization of the United Nations (FAO): Guidelines for soil description. 4th Edn., Food and Agricultural Organization of the United Nations, Rome (2006).

llies, G., llies, M. and Hotea, M.: Budesti. Maramures. In : Modele ale specificitatii regionale.Suport pentru strategiile de valorificare turistica a satului traditional romanesc [Regional specificity models. Handbook for rural tourism strategies in Romania's traditional villages] (Ed.: G. Ilies), Presa Universitara Clujeana, Cluj Napoca, p.99 (2010).

llies, M., M. Hotea and G. Ilies: Studii Asupra Zonei „Grupul de Acțiune Locală Mara-Gutâi" Maramureş. [Studies on the zone of the Local Action Group Mara - Gutai].Presa Universitara Clujeana, Cluj Napoca (2014).

Michaeli E., M. Ivanova and S. Koco: The evaluation of anthropogenic impact on the ecological stability of landscape. J. Environ. Biol., 36, Special Issue, 1-7 (2015).

Navrátil, J., J. Knotek, E. Hanzelková and K. Pícha: Tourists "Knowledge" of a Visited Environment and the Immediate Influence on this
Knowledge of Completing an Interpretive Nature Trail: Beskydy Protected Landscape Area, West Carpathians, GeoJournal of Tourism and Geosites, 18, 2, 145-151 (2016).

Pui, L.: The Igniş - Gutâi Mountain tourist planning in terms of a territorial system in Maramureş, Analele Universităţii din Oradea, 2, 308315, Oradea (2012).

Pui, L.: The development of the Igniş - Gutâi area by type of tourism, Analele Universităţii din Oradea, 1, 146-155, Oradea (2013).

Pletsch, M.A.J.S., V.F. Velázquez, J.M.A. Sobrinho, G.B. Borges and C.S. Coutinho: Geological and geomorphological elements as management tools in protected areas open to public use: A case study of the Pedroso's Natural Municipal Park, Santo André, Brazil, Geo. J. Tourism Geosites, 14, 2, 111-124 (2014).

Priess, J. A., and J. Hauck: Integrative scenario development. Ecol. Soc., 19, 12, (2014).

Priess, J.A. and J. Hauck: Scenario Building and its application. In: Open NESS Ecosystem Services Reference Book. (Eds. M. Potschin and K. Jax): EC FP7 Grant Agreement no. 308428. Available via: www.openness-project.eu/library/reference-book (2016).

Smith, A.C., P.M. Berry and P.A. Harrison: Sustainable ecosystem Management. In: open NESS ecosystem services reference book. (Eds. M. Potschin and K. Jax), EC FP7 Grant Agreement no. 308428. Available via: www.openness-project.eu/library/ reference-book (2016).

Zinck, J. A.: The Geomorphic landscape: Criteria for classifying geoforms. In: Geopedology: An Integration of geomorphology and pedology for soil and landscape studies . (Eds.: J.A. Zinck, G. Metternicht, G. Bocco and V. Del). Springer International Publishing, Berlin (2016).

UNDP/GEF: Evaluarea contribuţieie cosistemelor din ariile protejate la dezvoltarea economic şi bunăstarea umană în România [Evaluation of the ecosystem services to the development, economy and wellbeing of societies in the nature protection areas of Romania] (2012) , at http://undp.ro/libraries/projects/ Evaluarea_contributiei_ecosistemelor_din_ariile_protejate_la_d ezvoltarea_economica_si_bunastarea_umana_in_Romania.pdf, retrieved in September 2013.

World Wide Fund for Nature WWF Raport Anual 2010 WWF-România [Annual report of WWF Romania] (2010) at http://d2ouvy 59p0dg6k.cloudfront.net/downloads/raport_final2010.pdf 